\title{
Expression, purification and evaluation of recombinant $L$-asparaginase in mehthylotrophic yeast Pichia pastoris
}

\author{
Biểu hiện, tinh sạch và đánh giá hoạt tính của L-asparaginase tái tổ hợp trong \\ nấm men Pichia pastoris
}

Research article

Nguyen, Tien Cuong, Do, Thi Tuyen, Nguyen, Thi Hien Trang, Quyen, Dinh Thi*

Institute of Biotechnology, Vietnam Academy of Science and Technology

\begin{abstract}
L-asparaginase (EC 3.5.1.1), a therapeutic enzyme used in the treatment of childhood acute lymphoblastic leukemia (ALL). Hence, the goal of this work is study the expression and evaluation of hydrolysis activity of native sequence (X12746) encoding for L-asparaginase from Erwinia chrysanthemi NCPBB1125 in the popular expression system Pichia pastoris. The sequence of asn encoded for mature protein was expressed in P. pastoris SMD1168 and X33. SDS-PAGE analysis showed recombinant L-asparaginase was secreted efficiently. Stable and high hydrolysis activity of extracellular L-asparaginase in $P$. pastoris SMD1168 making it a potential candidate to produce recombinant protein. After purification, a specific band whose appearance approximately $45 \mathrm{kDa}$ indicating the glycosylated protein with specific activity by $6.251 \mathrm{Umg}^{-1}$ and about 3 folds purifications.
\end{abstract}

\begin{abstract}
L-asparaginase (EC 3.5.1.1), một loại enzyme được sủ dụng trong điều trị bệng ung thu bạch cầu mãn tính ở trẻ em. Mục tiêu của nghiên cứu này là biểu hiện và đánh giá hoạt tính thủy phân của L-asparaginase mã hóa bởi đoạn gene (X12746) tưong úng tù Erwinia chrysanthemi NCPBB1125 được biểu hiện trong nấm men Pichia pastoris. Gene đã được cắt signal peptide và biểu hiện trong P. pastoris SMD1168 and X33. Qua phân tích kết quả điện di SDS-PAGE của môi truờng sau lên men, L-asparaginase tái tổ hợp được tìm thấy trong dịch ngoại bào của P. pastoris.Với khả năng sản xuất protein có hoạt tính cao hơn so với chủng P. pastoris X33, SMD1168 được lự chon để biểu hiện L-asparaginase tái tổ hợp. Sau khi tinh sạch, sự xuất hiện của một băng có kich khối luợng phân tư xấp xỉ $45 \mathrm{kDa}$ trên điện di SDS-PAGE cho thấy protein tái tổ hợp đã bi glycosyl hóa với hoạt tính riêng 6.251 Umg-1 và đạt độ sạch 3.471 lần.
\end{abstract}

Keywords: L-asparaginase, Pichia pastoris, recombinant protein

\section{Introduction}

L-asparaginase (EC 3.5.1.1) was used as a chemotherapy regiment with other chemotherapy drugs including prednisolone, dexamethasone or vincristine in the treatment of childhood acute lymphoblastic leukemia (ALL). The molecular weight of L-asparaginase $\sim 140 \mathrm{kDa}$ composed by four identical sub units. Structural studies showed $E$. coli L-asparaginase (EcA) existed in two types: a low affinity enzyme EcAI in the cytoplasma and a high affinity periplasmic enzyme EcAII (Campbell et al., 1967; Sanches et al., 2007). As administrated in the body, the drug hydrolyze exogenous L-asparagine leading to the starvation of cancer cells which is the main reason of its apoptosis state. Besides, the toxic acrylamide in industrialized foods formed during browning process by Maillard reaction between the $\alpha$-amino group of free amino acid L-asparagines and carbonyl group of reducing sugar (Becalski et al., 2003) can be detected by of Lasparaginase reaction (Mashburn and Wriston, 1964) towards its substrates. Since the hydrolysis activity of Lasparaginase was first discovered by Lang in several beef tissues (Lang, 1904), the variable sources of Lasparaginase have been found including bacteria, yeast, fungi, plant, animal and even in soil (Kuldeep Kumar, 2012). Among of those, gene encoded for L-asparaginase (asn) from Escherichia coli and Erwinia has been used 
frequently for the production of recombinant Lasparaginase on the pharmaceutical market, but Erwinia L-asparaginase is more favour for patients with high sensitive toward EcA because of its low efficacy related to low toxicity (Mashburn and Landin, 1970; Adamson, 1971; Shifrin et al., 1973; Ashworth and MacLennan, 1974; Duval et al., 2002).

\section{Materials and methods}

In this study, gene encoded for L-asparaginase from $E r$. chrysanthemi NCPPB1125 was obtained from GenBank (X12746) was removed the signal sequence and expressed in $P$. pastoris SMD1168 and X33 (Invitrogen, USA). Other chemicals were purchased from Sigma-Aldrich and Merk (Germany).

\subsection{Construction of recombinant vector pPICZ $\alpha A$ and $a s n$ gene namely pPICZaAasn}

The signal peptide was removed using Signal IP 4.1 Server (at http://www.cbs.dtu.dk/services/SignalIP/) with two restriction sites of $P m l \mathrm{I}$ and $X b a l \mathrm{I}$ were designated at the two ends of sequence to ligate into vector pPICZ $\alpha \mathrm{A}$. Forward primer 5' - ATA TAT CAC GTG GGC CGA TAA ACT GCC GAA T - 3'and reverse primer 5' - ATA AAG TCT AGA GCG TAG GTA TGG AAG TAT TCT $\mathrm{T}-3 \overline{\text { ' have the }}$ restriction site underlined respectively. The total volume of PCR reaction is $25 \mu$ l containing: 15.5 $\mu 1 \mathrm{H}_{2} \mathrm{O} ; 2.5 \mu \mathrm{l} 10 \mathrm{X} P f u$ buffer (without $\mathrm{MgSO}_{4}$ ); $2 \mu \mathrm{l}$ dNTP $(2.5 \mathrm{mM}) ; 1.5 \mu 1 \mathrm{MgSO}_{4}(25 \mathrm{mM}) ; 1 \mu \mathrm{l}$ forward primer $\left(10 \mathrm{pM}^{-1} \mathrm{l}^{-1}\right) ; 1 \mu \mathrm{l}$ reverse primer $\left(10 \mathrm{pM} \mu \mathrm{l}^{-1}\right) ; 0.5$ $\mu 1 \mathrm{Pfu}$ DNA polymerase $\left(5 \mathrm{U}^{-1} \mathrm{l}^{-1}\right) ; 1 \mu \mathrm{l}$ DNA template (50-100 ng). Selected mode: $95 \mathrm{C} / 5^{\prime} ; 30$ cycles $\left(95 \mathrm{C} / 45^{\prime}\right.$; 54C/45"; 72 C/1'30"); 72 C/10'.

PCR product was purified by GeneJET PCR Purification Kit (Thermo, USA). The DNA copies was ligated to cloning vector pJET1.2/blunt (2974 bp) by the following mixture: $5.5 \mu 1 \mathrm{H}_{2} \mathrm{O} ; 1 \mu$ l buffer 10X T4 DNA ligase; $1 \mu 1$ T4 DNA ligase; $0.5 \mu$ l vector pJET1.2/blunt; $1.5 \mu 1$ PCR product of asn gene. The mixture was incubated at $22 \mathrm{C}$ for 16 hours.

The recombinant plasmid was transformed into $E$. coli DH10B competent cells using heat shock methods and screened on Luria Agar (LA) dish with additional ampi-

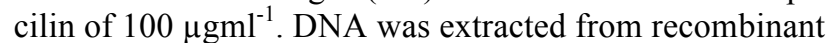
vector using Accuprep ${ }^{\circledR}$ Gel Extraction Kit (Bioneer, USA) and ligated to expression vector $\mathrm{pPICZ} \alpha \mathrm{A}$.

The resulting recombinant vector namely pPICZ $\alpha$ Aasn was transformed into competent cells of $P$. pastoris SMD1168 and X33 by the procedure described in Pichia Expression Kit (Invitrogen, Catalog no. K1710-01). The recombinant colonies was screened on YPD agar dish including yeast extract $1 \%(\mathrm{w} / \mathrm{v})$, peptone-A $2 \%(\mathrm{w} / \mathrm{v}), \mathrm{D}$ sorbitol $2 \%(\mathrm{w} / \mathrm{v})$ with additional $25 \mu \mathrm{gml}^{-1}$ Zeocine $^{\circledR}$. To check the insertion of asn gene into P. pastoris, AOX forward primer 5' - GAC TGG TTC CAA TTG ACA AGC - 3' and reverse primer 5' - GCA AAT GGC ATT CTG ACA TCC - 3' was used in PCR experiment. DNA template of recombinant $P$. pastoris was prepared by method described by Looke (Looke et al., 2011). The PCR selected mode was similar as that using asn gene.

\subsection{Expression of recombinant $L-$ asparaginase in methyl tropholic yeast $P$. pastoris}

One colony of recombinant $P$. pastoris strain habouring plasmid pPICZ $\alpha$ Aasn was cultured in $5 \mathrm{ml} \mathrm{YP} \mathrm{with} \mathrm{glyc-}$ erol $1 \%(\mathrm{v} / \mathrm{v})$ in 16-18 hours. The inoculated media was added to $250 \mathrm{ml}$ media in a shake flask $1 \mathrm{~L}$ by $1 \%(\mathrm{v} / \mathrm{v})$ for induction with $0.5 \%$ absolute methanol. This carbon source was added to the media each 24 hours.

\subsection{Purification of recombinant L-asparaginase}

Ni-NTA column was used to purify recombinant Lasparaginase which has a high affinity for recombinant proteins according to the instruction of ProBond ${ }^{\mathrm{TM}}$ NikelChelating Resin (Invitrogen, USA).

For recombinant protein in methyltropholic yeast, the culture supernatant was collected 48 hours after induction by centrifuging the cell at $4000 \mathrm{rpm}$ for 15 minutes at $4 \mathrm{C}$ and this was used for purification of recombinant $\mathrm{L}$ asparaginase by Ni-NTA affinity chromatography. A column was added $2 \mathrm{ml}$ Ni-NTA resin and equilibrated with $8 \mathrm{ml}$ binding buffer $\left(\mathrm{NaH}_{2} \mathrm{PO}_{4} 250 \mathrm{mM}\right.$; $\mathrm{NaCl} 2.5$ $\mathrm{mM}$; imidazole $10 \mathrm{mM}$; $\mathrm{pH} 8.0$ ). $8 \mathrm{ml}$ of culture supernatant was loaded on to the Ni-NTA column. The column was washed with $24 \mathrm{ml}$ of washing buffer $\left(\mathrm{NaH}_{2} \mathrm{PO}_{4} 250\right.$ $\mathrm{mM}$; $\mathrm{NaCl} 2.5 \mathrm{mM}$; imidazole $20 \mathrm{mM}$; $\mathrm{pH} 8.0$ ) and protein was eluted with elution buffer $\left(\mathrm{NaH}_{2} \mathrm{PO}_{4} 250 \mathrm{mM}\right.$; $\mathrm{NaCl} 2.5 \mathrm{mM}$; imidazole $250 \mathrm{mM}$; $\mathrm{pH} 8.0$ ). Fractions of 1 $\mathrm{ml}$ were collected and analyzed by SDS-PAGE.

\subsection{Enzyme assay}

\subsubsection{Protein concentration}

The concentrations of protein L-asparaginase were determined using the method of Bradford (Bradford, 1976). Bovine serum albumin (BSA) was used as the standard protein.

\subsubsection{L-asparaginase activity}

Enzyme activity of recombinant L-asparaginase was measured by method introducing in previous study (Mashburn and Wriston, 1964) in which the rate of ammonia formation will be detected by Nessler's reagent at $37 \mathrm{C}$. One unit of L-asparaginase activity was determined as the amount of enzyme that librates $1 \mu \mathrm{mol}$ of ammonia from L-asparaginase per minute at $37 \mathrm{C}$.

\section{Results and discussions}

\subsection{Construction of recombinant vector}




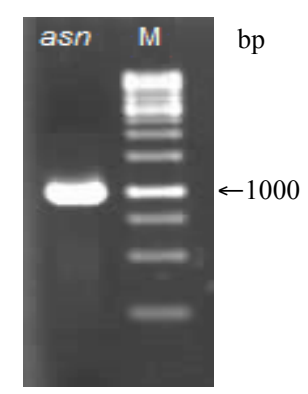

A

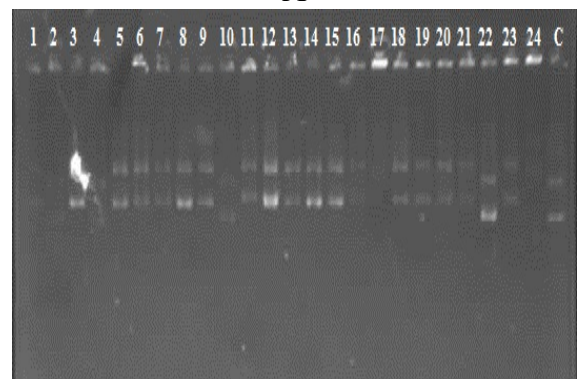

$\mathrm{D}$

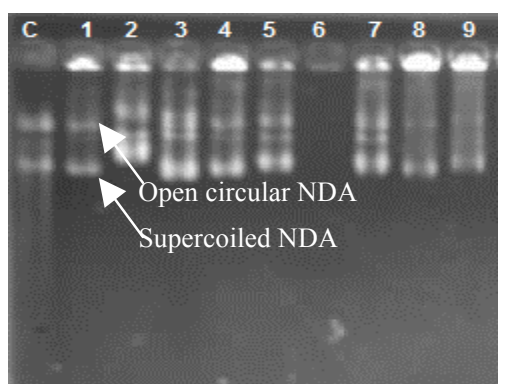

B

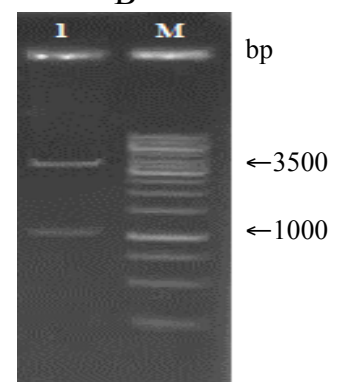

$\mathrm{E}$
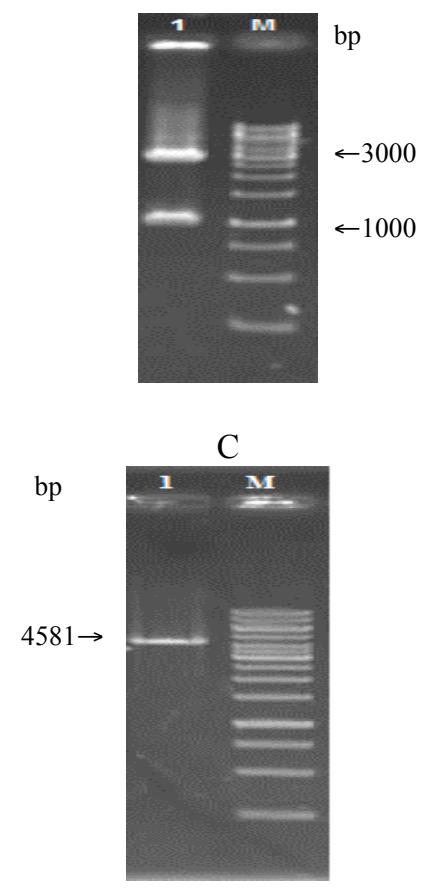

$\mathrm{F}$

Figure 1. Construction of recombinant vector pPICaZAasn. DNA electrophoresis (A) PCR product of gene encoded L-asparaginase from Er. chrysanthemi NCPPB1125 with 2 restriction sites of PmlI and XbalI; (B) Recombinant cloning vector , C - pJET1.2/blunt; (C) Digestion of recombinant cloning plasmid; (D) Recombinant expression vector, C- pPICZaA ; (E) Digestion of recombinant expression plasmid; (F) Lineared pPICZaAasn. M: DNA ladder $10 \mathrm{kbps}$

The PCR product on electrophoresis gel showed a band near the position of $1000 \mathrm{~kb}$ ladder indicating the asn gene with the molecular weight of 981 bp (Fig. 1A). An insertion event of asn gene into cloning vector pJET1.2/blunt was showed on electrophoresis gel resulting a higher molecular weight of recombinant cloning vector in comparison with "empty" vector which represented by lane 2 (Fig. 1B). The expected results should be one band of interested plasmid but in every lane, two visible bands could be seen clearly, it is important to realize there are five types of plasmid in order of electrophoresis mobility including nicked open-circular DNA, relaxed circular DNA, linear DNA, supercoiled DNA and supercoiled denatured DNA. On the electrophoresis gel, there are usually two types of plasmid such as supercoiled DNA and open-circular DNA, and other bands corre-

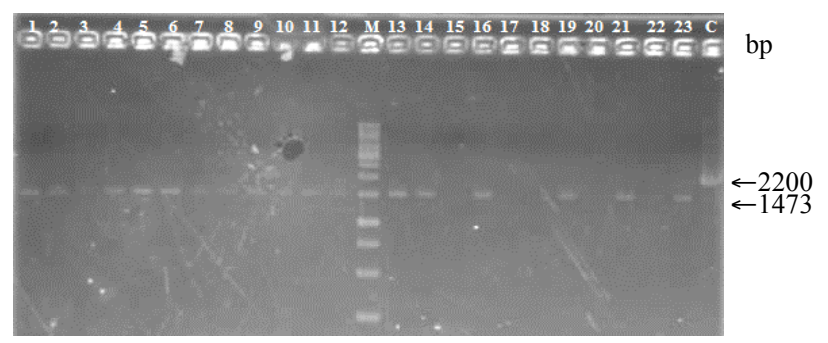

A

Figure 2. DNA electrophoresis of PCR product of DNA extracted from recombinant $P$. pastoris SMD1168 (A) and $X 33$ (B) using $A O X$ primers with $C$ (control) are those of $P$. pastoris SMD1168 and X33 without the inserted gene respectively. M: DNA ladder $10 \mathrm{kbps}$

As can be seen, the result showed there is one band of wild-type $(2200 \mathrm{bp})$ and one band near the position of sponding to different form of plasmids. The rate of migration of plasmid on the gel is proportional with applied voltage so open-circular DNA migrates slower than supercoiled DNA because of its stretched conformation. The insertion of asn gene into cloning vector was confirmed again by the digestion of two restriction enzymes $P m l \mathrm{I}$ and $X b a l \mathrm{I}$ at the two ends of sequence (Fig. 1C). Next, foreign gene was inserted into vector pPICZ $\alpha$ A, the heavier molecular weight of recombinant vector corresponds to lane 1-21 and lane 23-24 indicating the insertion of asn gene (Fig. 1D). This was confirmed again by using two restriction enzymes resulting one band of interested gene and one band of pPICZ $\alpha \mathrm{A}(3600 \mathrm{bp})$ on the electrophoresis gel (Fig. 1E). For transformation into $P$. pastoris cells, the recombinant vector was linear (4581 bp) for integration into yeast genome (Fig. 1F).

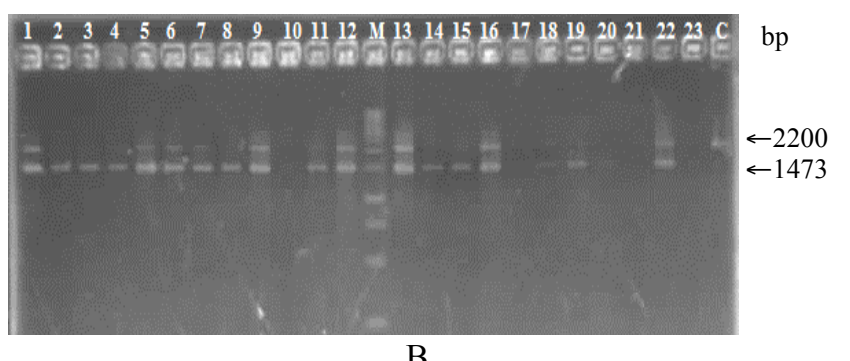

$\mathrm{B}$

$1500 \mathrm{bp}$ ladder which equivalents to the inserted gene (981 bp) plus $A O X$ primer (492 bp) (Fig. 2). This con- 
firms the foreign gene had been integrated into P. pastoris

\subsection{Extracellular proteins in P.pastoris}

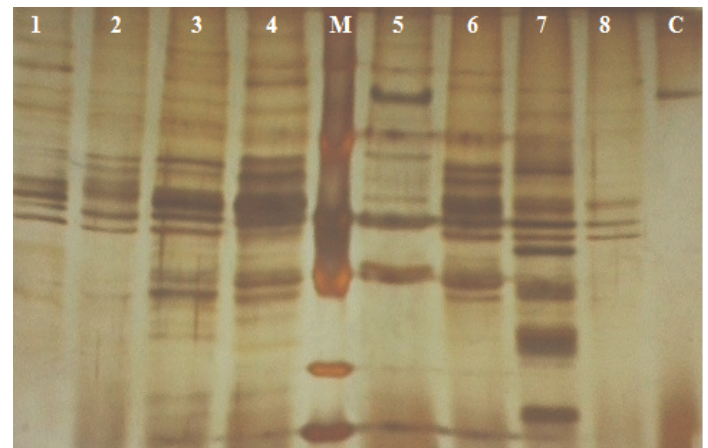

A

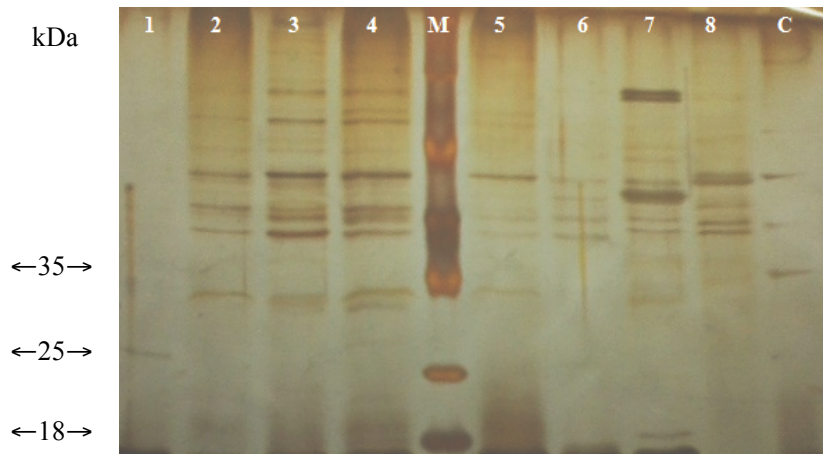

B

Figure 3. SDS-PAGE of crude supernatant of recombinant $P$. pastoris SMD1168 (A) and X33 (B); C (control) are that of $P$. pastoris SMD1168 and X33 without asn gene respectively. M: Protein marker.

The appearance of several bands on electrophoresis gel indicated the recombinant L-asparaginase was secreted efficiently into the broth. In contrast, the heterologous Lasparaginase encoded by ASP3 gene of Saccharomyces cerevisae was expessed in P. pastoris GS115 was intracellular proteins (Ferrara et al., 2006). Thus, the supernatant was used to evaluate the L-asparaginase activity.

\subsection{Determination L-asparaginase activity from fer- mented supernatant}

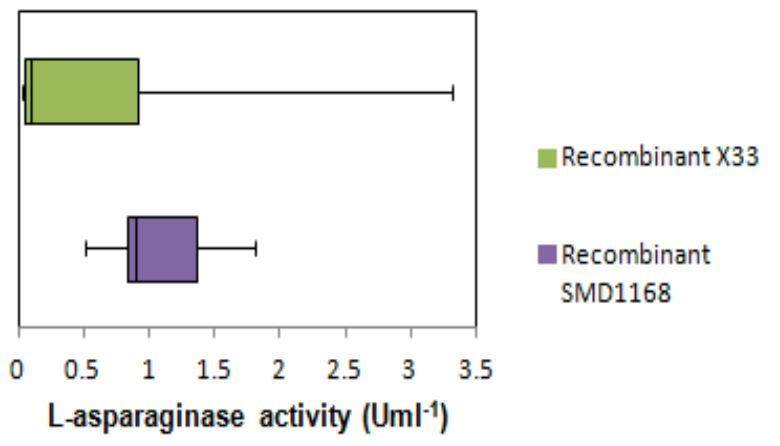

Figure 4. L-asparaginase activity of crude supernatant of recombinant $P$. pastoris SMD1168 and X33

The distribution of data (Fig. 4) of hydrolysis activity of two recombinant strains revealed the recombinant Lasparaginase in $P$. pastoris SMD1168 is more favored than that in $P$. pastoris X33. One factor contributes for this difference can be explained by the efficiency of transformation (Fig. 2A) in which the number of homozygous double transformants are minority in $P$. pastoris $\mathrm{X} 33$. The highest activity of recombinant L-asparaginase in crude extract recorded of $P$. pastoris X33 was $3.3 \mathrm{Uml}^{-1}$ while in $P$. pastoris SMD1168 was $1.8 \mathrm{Uml}^{-1}$.

\subsection{Purification and evaluation of recombinant $L$ - asparaginase}

The recombinant L-asparaginase was fused with 6xHis tag has a high affinity with Ni-NTA column so the heter- ologous protein accumulated in elution fragment corresponding to desired proteins

The appearance of a single band at lane 5 and lane 6 (Fig. 5) $\sim 45 \mathrm{kDa}$ of ladder protein indicated the recombinant L-asparaginase. The unexpected higher molecular mass can be explained by the glycosylation in P. pastoris. The purified protein was used to evaluate the hydrolysis activity of recombinant L-asparaginase.

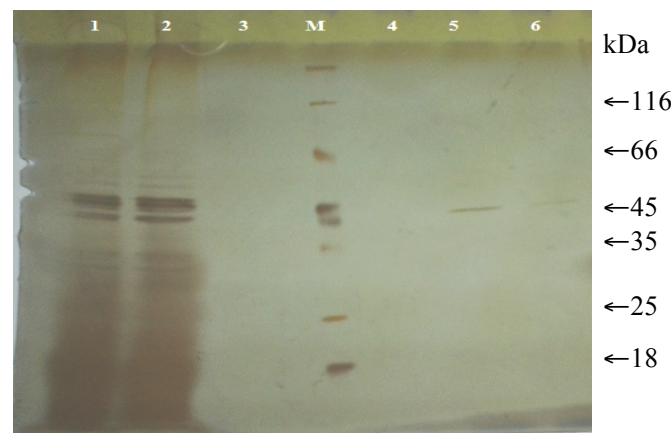

Figure 5. Purification of supernatant of a recombinant P. pastoris SMD1168 (Lane 1: Crude supernatant; Lane 2: Flow through; Lane 3: Wash; Lane 4 - 6: Elution fragments)

The appearance of a single band obtained after the supernatant had flowed through the affinity chromatography column was $\sim 45 \mathrm{kDa}$ marker (Fig. 5) indicate the expected extracellular L-asparaginase. In fact, the molecular weight was higher than predicted value $(\sim 35 \mathrm{kDa})$. This difference can be explained by the contribution of glycosylations to the molecular mass of protein molecule because of the adjacent $O$-linked (hydroxyl group of serine, threonine or hydroxylisine) and $N$-linked (group of asparagines carbohydrate chains) to heterologous proteins in P. pastoris (Lin-Cereghino et al., 2002). This was also observed when recombinant L-asparaginase was produced in $P$. pastoris GS115 possessing a molecule mass of $\sim 45$ $\mathrm{kDa}$ (Ferrara et al., 2010) higher than expected of $\sim 35$ $\mathrm{kDa}$ (Ferrara et al., 2006), the difference of the Lasparaginase band on electrophoresis gel can be explained by different glycosylation degrees. Accordingly, the ma- 
ture protein was predicted to have 4 potential $O$-linked sites by NetOGly 4.0 (available at http://www.cbs.dtu.dk/ services/NetOGlyc/) and 4 potential $N$-linked sites by NetNGly $\quad 1.0 \quad$ (http://www.cbs.dtu.dk/services/ NetNGlyc/). The specific activity of recombinant Lasparaginase in P. pastoris SMD1168 after affinity step obtained by $6.251 \mathrm{Umg}^{-1}$ with a recovery rate of $16.667 \%$ and 3.471 fold purification. The values obtained from this result are higher than that of intracellular proteins in $P$. pastoris GS115 of $800 \mathrm{Ug}^{-1}$ (Ferrara et al., 2006) but lower when the extraction procedure of heterologous protein was selected respectively $\sim 15000 \mathrm{Umg}^{-1}$ (Ferrara et al., 2010).

\section{Conclusions}

We have cloned the asn gene from Er. chrysanthemi NCPPB1125 and expressed successfully in P. pastoris SMD1168 and X33. The recombinant L-asparaginase was secreted efficiently into the media. Afer purification, a specfic band $\sim 45 \mathrm{kDa}$ implied the desired protein with the specific activity by $6.251 \mathrm{Umg}^{-1}$, the recovery rate by $16.67 \%$ and $\sim 3$ fold purification. Characterization and optimization of this protein can be accessed in the next works.

\section{References}

[1] Adamson, R.H. (1971). Some aspects of Lasparaginase activity in animals and man. . Colloq. Intern. Centre NatI. Rech. Sci. Paris. 197, 189-193.

[2] Ashworth, L.A.E., and MacLennan, A.P. (1974). Comparison of the L-asparaginase from Escherichia coli and Erwinia carotovora as immunosuppresants. Cancer research. 34, 1353-1359.

[3] Becalski, A., Lau, B.P.Y., Lewis, D., and Seaman, S.W. (2003). Acrylamide in foods: occurence, sources, and modeling. J. Agric. Food. Chem. 51, 802-808.

[4] Bradford, M.M. (1976). A rapid and sensitive method for the quantification of microgram quantities of protein utilizing the principle of protein-dye binding. Anal. Biochem. 72, 248-254.

[5] Campbell, H.A., Mashburn, L.T., Boyse, E.A., and Old, L.J. (1967). Two L-asparaginase from Escherichia coli $\mathrm{B}$. Their separation, purification and antitumor activity. Biochemistry. 6, 721-730.

[6] Duval, M., Suciu, S., Ferster, A., Rialland, X., Nelken, B., Lutz, P., Benoit, Y., Robert, A., Manel, A.M.,
Vilmer, E., Otten, J., and Phillippe, N. (2002). Comparison of Escherichia coli-asparaginase with Erwinia-asparaginase in the treatment of childhood lymphoid malignancies: results of a randomised European Organisation for Research and Treatment of Cancer-Children's Leukemia Group phase 3 trial. Blood. 99, 2734-2739.

[7] Ferrara, M.A., Severino, N.M.B., Valente, R.H., Perales, J., and Bon, E.P.S. (2010). High-yield extraction of periplasmic asparaginase produced by recombinant Pichia pastoris harbouring the Saccharomyces cerevisae ASP3 gene. Enzyme and Microbial Technology. 47, 71-76.

[8] Ferrara, M.A., Severino, N.M.B., Mansure, J.J., Martins, A.S., Oliveira, E.M.M., Siani, A.C., N., P.J., Torres, F.A.G., and S., B.E.P. (2006). Asparaginase production by a recombinant Pichia pastoris strain harbouring Saccharomyces cerevisiae ASP3 gene. Enzyme and Microbial Technology 39, 14571463.

[9] Kuldeep Kumar, N.V. (2012). The Various Sources \& Application of L-Asparaginase. Asian Journal of Biochemical and Pharmaceutical Research. 2, 22312560

[10] Lang. (1904). Über desamidierung im Tierkörper. Beitr chem Physiol Pathol. 5, 321-345.

[11] Lin-Cereghino, G.P., Lin-Cereghino, J., Ilgen, C., and Cregg, J.M. (2002). Production of recombinant proteins in fermenter cultures of the yeast Pichia pastoris. Curr. Opin. Biotech. 13, 329-332.

[12] Looke, M., Kristjuhan, K., and Kristjuhan, A. (2011). Extraction of genomic DNA from yeasts for PCR based applications. Biotechniques 50, 325-328.

[13] Mashburn, L.T., and Wriston, J.C.J. (1964). Tumor inhibitory effect of L-asparaginase from Escheria coli Arch Biochem Biophys 105, 450-452.

[14] Mashburn, L.T., and Landin, L.M. (1970). Some physicochemical aspects of L-asparaginase therapy. Recent. Results. Cancer. Res. 33, 48-57.

[15] Sanches, M., Krauchenco, S., and Polikarpov, I. (2007). Structure , substrate complexation and reaction mechanism of bacterial asparaginases. Curr. Chem. Biol. 1, 75-86.

[16] Shifrin, S., Solis, B.G., and Chaiken, I.M. (1973). Lasparaginase from Erwinia carotovora: Physicochemical properties of the native and succinylated enzyme. J. Bio. Chem. 248, 3464-3469. 